\title{
Student's Analytical and Synthetic Thinking Level in Solve Linear Programming
}

\author{
Kriswandani ${ }^{1}$, Cholis Sa' ${ }^{\prime}{ }^{1 j j a h}{ }^{2}$, Santi Irawati ${ }^{2}$, Erry Hidayanto ${ }^{2}$ \\ \{kriswandani.1703119@student.um.ac.id, cholis.sadijah.fmipa@um.ac.id, \\ santi.irawati.fmipa@um.ac.id, erry.hidayanto.fmipa@um.ac.id\} \\ ${ }^{1}$ Student of Postgraduate Mathematics Education Program Malang State University \\ ${ }^{2}$ Lecture of Postgraduate Mathematics Education Program Malang State University
}

\begin{abstract}
Analysis and synthesis are higher level thinking skills that are fundamental in creative thinking. This research is a qualitative method to identify the analytical and synthetic level of thinking of students in solving linear programming problems. Twentythree students from the 2018 class of the Mathematics Education Program of UKSW participated in this study. The data collection instruments of this research were 5 linear program essays categorized into 5 types of problems, which were dismemberments of the whole into its component parts problems, establishment of relationships between the parts of the whole problems, integration by parts problems, solution planning problems, and error finding problem with an explanation of the error reason. This result shows that the level of analytical and synthetic thinking skills of students in the 2018 class of the Mathematics Education Program of UKSW are relatively low. For dismemberments of the whole into its component parts problems and establishment of relationships between the parts of the whole problems, most of the students achieved until the attributing stage, but more complex problem i.e. integration by parts problems, the students only achieved the differentiating stage. For solution planning problems, and error finding problem with an explanation of the error reason, most of the students only achieved the generating stage.
\end{abstract}

Keywords: Analytical Thinking, Synthetic Thinking, Linear Programming Problem, Bloom Taxonomy.

\section{Introduction}

Bloom's Taxonomy divides the learning domain into three categories, which are cognitive (six levels), affective (five levels), and psychomotor (six levels). The cognitive domain consists of (a) knowledge, (b) comprehension, (c) application, (d) analysis, (e) synthesis, and (f) evaluation. However, Bloom's Taxonomy was revised and the cognitive domain has changed to (a) remember, (b) understand, (c) apply, (d) analyze, (e) evaluate, and (f) create $[1,2]$. This revision changed every categorical level description on the old Bloom's Taxonomy from a noun to a verb. Other changes were that evaluation was moved to level five and that synthesis was replaced by create and moved to level six. Based on these six cognitive levels, the first three levels are categorized as lower order thinking skills (LOTS), and the next three levels are categorized as higher order thinking skills (HOTS). The HOTS of a person will appear when encountering unfamiliar problems, uncertainties, questions, or dilemmas [3]. 
Analytical and synthetic are two rarely examined HOTS. Even though there is an evaluate level between analysis and synthesis, they are two connected thinking abilities and have important roles. To be able to work creatively, a balance between three thinking abilities is needed, such as analysis, synthesis, and practicality. In other words, analysis and synthesis are creativity requirements [4]. Analysis and synthesis play an important role in the cognitive process and based on preliminary research, analytical thinking and synthetic thinking also play a role in the development of other thinking skills $[5,6,7,8,9,10,11,12]$. The combination of analysis and synthesis is systemic thinking where it affects the fields of business, economy, leadership in organization, psychology, and others $[13,14,15,16,17,18]$. Systemic thinking is a simple thinking technique for gaining systemic (situation-wide) insights into complex situation and problems $[19,20]$.

Analytical as the ability to decipher a material into component parts so that the structure can be understood. Analytical thinking as a powerful thinking tool for understanding the parts of a situation. It is defined as (a) the ability to scrutinize and break down facts and thoughts into their strengths and weaknesses and (b) developing the capacity to think in a thoughtful, discerning way to solve problems, analyze data, and recall and use information [19]. Analysis as the classification of elements into sections to find the origin and how these elements are interrelated [21]. Analysis activity includes identifying material parts, examining the relationship between parts and the whole, and recognizing the principles of preparing the material. Based on Bloom Taxonomy, indicator of analytical thinking includes differentiating (D), organizing $(\mathrm{O})$ and attributing $(\mathrm{A})$. Other side, synthesis is the union of elements and parts to form a whole. Synthesis is also defined as activity to determine a new creation with the combination of ideas from various sources [22]. Synthesis (creating) is an activity that integrates parts of information to form a new design. Activity in synthesis produces a unique communication language, an intact plan or activity, and a set of abstract relationships. Based on Bloom Taxonomy, indicator of analytical thinking includes generating $(\mathrm{G})$, planning (Pl), and Producing $(\mathrm{P})$.

Analysis is a general logical method of mental activity and significance in human life. The types and forms of analysis include dismemberment of the whole into its component parts, establishment of relationships between the parts of the whole, analysis as the basis for classifying items, and retrospective analysis. Whereas synthesis is a general logical method of mental activity and its application has significance in human life. The types and forms of synthesis include synthesis as a result of analysis and anticipating synthesis. To identify analytical and synthetic skills, we can use dismemberment of the whole into its component parts problems, establishment of relationships between the parts of the whole problems, integration by parts problems, solution planning problems, and error finding problems with explanations of the error reasons [5]. We can describe analysis and Synthesis in Figure 1.

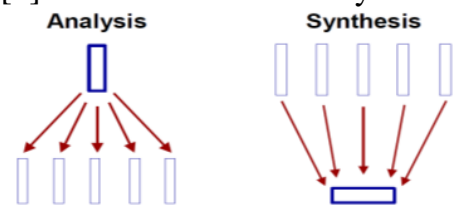

Fig. 1. Analysis and Synthesis adapted from Barttlet (2001).

This research will identify analytical and synthetic thinking skills level of first year students in linear program material. This material is one of mathematics' topics in grade 11 . Characteristics of linear program material include story problems and use of the system 
principles of linear inequality. To solve these problems, analytical and synthetic skills are needed.

\section{Research Methodology}

The respondents in this research were students in the class of 2018 in the Mathematics Education Program of UKSW. There were 21 students consisting of 19 female students and two male students. Data collection instruments used in this study were test essays. The tests consisted of five items about linear programming and were type of problem include dismemberments of the whole into its component parts problems, establishment of relationships between the parts of the whole problems, integration by parts problems, solution planning problems, and error finding problems with an explanation of the error reason.

Task 1. The calorie and protein content of beef and fresh fish and the price per $\mathrm{kg}$ sold at the traditional market is as follows: The calorie content in beef is 750 calories per $\mathrm{kg}$, while the calorie content in fresh fish is 450 calories per $\mathrm{kg}$. The protein content in beef is 300 units per $\mathrm{kg}$ and the price is Rp 140,000.00 per kilograms. Whereas for fresh fish, its protein content is 600 units per kilograms with a price of Rp 35,000.00 per kilograms. To treat patients, a hospital needs at least 225,000 calorie units and 195,000 protein units per day

a. Specify how much beef and fresh fish (in kilograms) a hospital provides to cost as little as possible!

b. Pretend there is a promotion program in two supermarkets as follows.
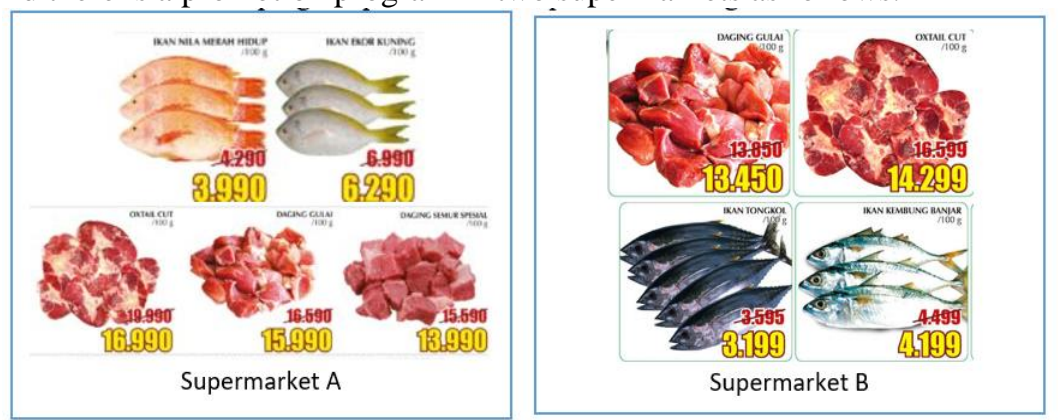

What option you think will be taken to buy for hospital needs on the promo day? Do you choose to shop at the traditional market or at Supermarket A or B? Provide some reasons!

Task 2. Dona bought 240 bottles of soy milk for sale. She rented two kinds of containers to carry the soy milk. The large container has the capacity to hold six bottles and the small container has the capacity to hold four bottles. The price of each container in a row is $\mathrm{Rp}$ 6,000.00 and Rp 5,000.00 in one go. How many large and small containers can be rented so that the cost Dona spends is as little as possible? If Dona's car capacity is able to only load 48 containers, how many large and small containers could Dona bring?

Task 3. Mrs. Kartika baked 2 types of cookies, they are nastar (pineapples cookies) and kaasstengels.

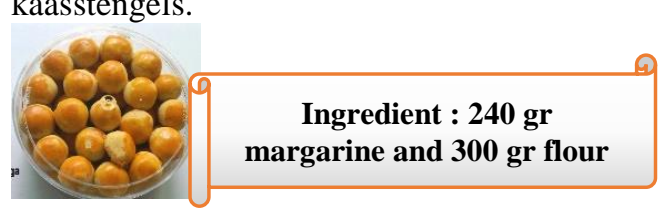

Ingredient : 120 gr margarine and 500 gr flour 
Two types of cookie ingredients needed are margarine and flour. Mrs. Kartika bought 9,600 g of margarine and $26 \mathrm{~kg}$ of flour. For her first plan, Mrs. Kartika wants to use all the ingredients to make kaasstengels where the amount is not more than twice as much nastar. For her second plan, Mrs. Kartika wants to use all the ingredients to make five times more nastar than kaasstengels. If each recipe produces 2.5 jars of nastar and 2.5 jars of kaasstengels, and the profit Mrs. Kartika gets is 10,000/jar for nastar and 12,000/jars for kaasstengels, then

a. How many jars of nastar and kaasstengels each were produced from Mrs. Kartika's first and second plan?

b. From the first and second plan, is there any jar that is not fully loaded? What is the reason?

c. How much profit Mrs. Kartika would get if she did her first plan? What if she did her second plan; how much profit would she get? Between these two plans, which will gain a small profit?

d. There are some choices of flour and margarine:

Margarine A: Rp 22,000.00/kg; Margarine B: Rp 17,000.00/kg; Margarine C: Rp $18,000.00 / \mathrm{kg}$

Flour A (high protein): Rp 11,000.00/pack; Flour B (medium protein): Rp 10,000.00/pack; Flour C (low protein): Rp 9,000.00/pack

Butter A (low quality): Rp 26,000.00/kg; Butter B (medium quality): Rp 60,000.00/kg; Butter C (high quality): Rp 280,000.00/kg

To make the cookies taste good, Mrs. Kartika mixed butter into margarine. Mrs. Kartika usually uses butter and margarine at 1:1. For cookies, Mrs. Kartika uses medium protein flour or low protein flour. For the cost of other ingredients, such as eggs to gas, is $\mathrm{Rp}$ 18,000.00/jar for nastar and Rp 40,000.00/jar for kaasstengels. Make a price variation plan for nastar and kaasstengels per jar by considering operational costs incurred by Mrs. Kartika!

If Mrs. Kartika gets an order of 60 jars of nastar and 80 jars of kaasstengels in medium quality, then how much money would Mrs. Kartika get?

Task 4. It is known that in the linear inequality system of a linear program problem,

$$
\left\{\begin{array}{c}
a x+b y(\geq, \leq) c ; a \neq 0, b \neq 0 \\
p x+q y(\geq, \leq) t ; p \neq 0, q \neq 0 \\
x \geq 0 \\
y \geq 0
\end{array}\right.
$$

$a, b, c, p, q$, and $t$ are real numbers, and $c<t$.

Observe the requirements of the linear inequality system:

a. No solution area

b. Have solution area

c. Have solution area in the form of a line and a line segment

d. Have solution area with only one point

Task 5. Plan an inequality system that meets every completion area below.

a. Have equilateral triangle form on the first quadrant

b. Have trapezoid form on the second quadrant

c. Have parallelogram form on the fourth quadrant

Table 1. Level, Criteria and Indicators of formation for skills that are parts of the analytic and synthetic activity (adopted [5])

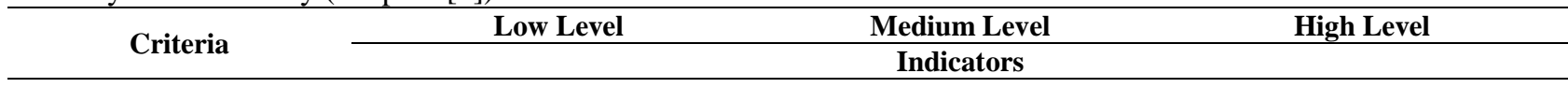




\begin{tabular}{|c|c|c|c|}
\hline $\begin{array}{l}\text { Ability to dismember the } \\
\text { whole into its component } \\
\text { parts }\end{array}$ & $\begin{array}{l}\text { - Distinguishing components in } \\
\text { the problem situation } \\
\text { - Distinguishing the processes } \\
\text { in which the component are } \\
\text { part in the problem situation }\end{array}$ & 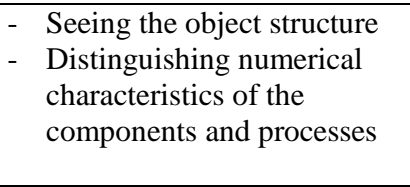 & $\begin{array}{l}\text { - Possessing the structural } \\
\text { vision of the object } \\
\text { - Finding non-standard ways to } \\
\text { solve the problem }\end{array}$ \\
\hline $\begin{array}{l}\text { Ability to establish } \\
\text { relationships between } \\
\text { parts of the whole }\end{array}$ & $\begin{array}{l}\text { - Finding dependencies } \\
\text { between the components } \\
\text { - Expressing some values } \\
\text { through others }\end{array}$ & $\begin{array}{l}\text { - Identifying significant data } \\
\text { relationships in the problem } \\
\text { situation } \\
\text { - Searching for new data } \\
\text { through the correlation of } \\
\text { the problem situation with } \\
\text { its requirements }\end{array}$ & 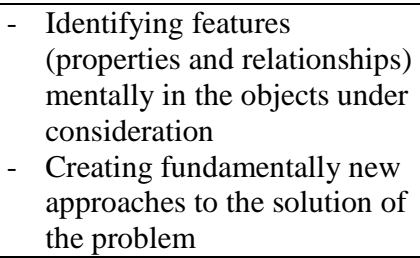 \\
\hline $\begin{array}{l}\text { Ability to make up the } \\
\text { whole from the parts }\end{array}$ & $\begin{array}{l}\text { - Identifying common and } \\
\text { distinctive features in the } \\
\text { objects, and the relationships } \\
\text { between them; } \\
\text { - finding similarities between } \\
\text { the objects; } \\
\text { - forming connections. }\end{array}$ & $\begin{array}{l}\text { - } \text { finding analogies; } \\
\text { - } \text { making generalization; } \\
\text { - } \text { connecting knowledge } \\
\text { components; } \\
\text { - } \text { formulating conclusions } \\
\text { independently. }\end{array}$ & $\begin{array}{l}\text { - connecting abstract concepts } \\
\text { with particular ones; } \\
\text { - } \text { operating with fuzzy } \\
\text { concepts; } \\
\text { - } \text { showing a creative approach } \\
\text { to solving problems. }\end{array}$ \\
\hline $\begin{array}{l}\text { Ability to draw an action } \\
\text { plan for problem solving }\end{array}$ & 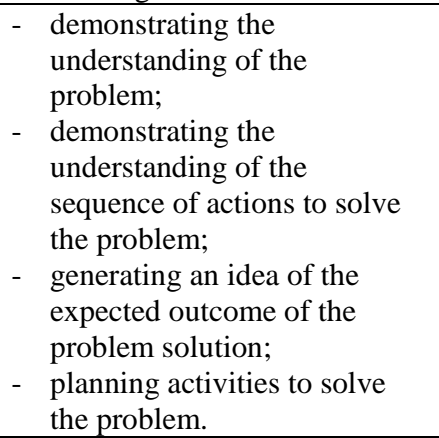 & 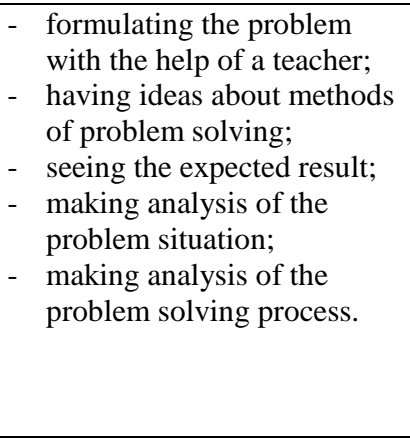 & $\begin{array}{l}\text { formulating and analyzing } \\
\text { the problem independently; } \\
\text { - defining a plan for solving } \\
\text { the problem; } \\
\text { - making analysis of the } \\
\text { problem solving methods; } \\
\text { - making an objective analysis } \\
\text { of the results of solving the } \\
\text { problem. }\end{array}$ \\
\hline $\begin{array}{l}\text { Ability to find errors and } \\
\text { explain their reasons }\end{array}$ & $\begin{array}{l}\text { - } \text { adducing arguments that } \\
\text { confirm availability of errors; } \\
\text { - } \text { presenting facts explaining } \\
\text { the reasons of the errors. }\end{array}$ & $\begin{array}{l}\text { - evaluating the results } \\
\text { obtained in accordance } \\
\text { with the available errors; } \\
\text { - identifying the nonessential } \\
\text { moments. }\end{array}$ & $\begin{array}{l}\text { - } \text { suggesting ways to eliminate } \\
\text { errors; } \\
\text { - making analysis of the work } \\
\text { results on the reasons of } \\
\text { errors. }\end{array}$ \\
\hline
\end{tabular}

\section{Results And Discussion}

Students' correct answers for each analytical stage can be seen in Table 2 below

Table 2. Analytical stage achieved by students for each problem

\begin{tabular}{lccc}
\hline & Differentiating & Organizing & Attributing \\
\hline Task 1 & 15 & 5 & 1 \\
\cline { 2 - 4 } & $71.43 \%$ & $23.81 \%$ & $4.76 \%$ \\
\hline Task 2 & 15 & 2 & 4 \\
\cline { 2 - 4 } & $71.43 \%$ & $9.52 \%$ & $19.05 \%$ \\
\hline Task 3 & 1 & 0 & 0 \\
& $4.76 \%$ & $0 \%$ & $0 \%$ \\
\hline
\end{tabular}


For dismemberments of the whole into its component parts problems, most of the students achieved until the attributing stage. For establishment of relationships between the parts of the whole problems, most of the students also achieved until the attributing stage. But for more complex problem i.e. integration by parts problems, the students only achieved the differentiating stage. It's means that students have low level of analytical thinking ability so they can solve simple problem but they can't solve more complex problem. Therefore, we need effort to develop the analytical thinking ability of students.

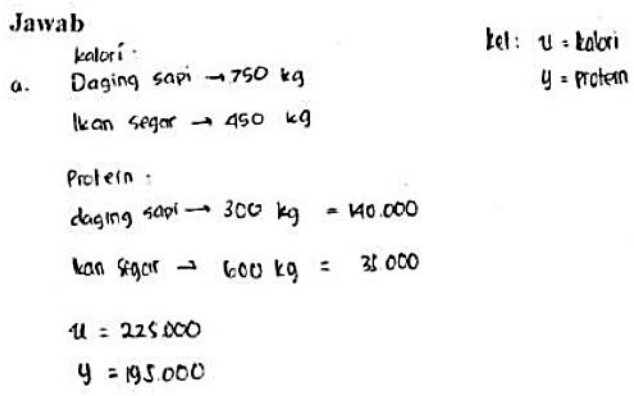

Fig 2. Example of a students' incorrect answer in determining the variable and in classifying information from Task 1.

This student was wrong in determining the variable where the symbol $x$ was the variable for the number of calories needed and the symbol $y$ was for the amount of protein needed. Moreover, the student is less systematic in classifying information known in the question.

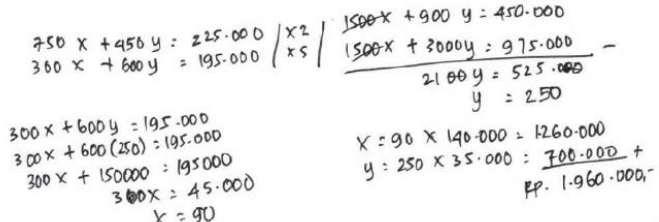

Fig 3. Example of a student's answer on task 1 in determining the wrong mathematic model, which is in the form of the linear equality system

Students are always taught by the teacher to work on the linear inequality system with the linear equation system so that students often understand a question about the linear inequality system as a question about the linear equation system. I think, this is a reason why students can't determine solution means of the linear inequality system model and graph of the linear inequality system. Students can determine the solution of the linear inequality system but they didn't understand of the linear inequality system principles. 

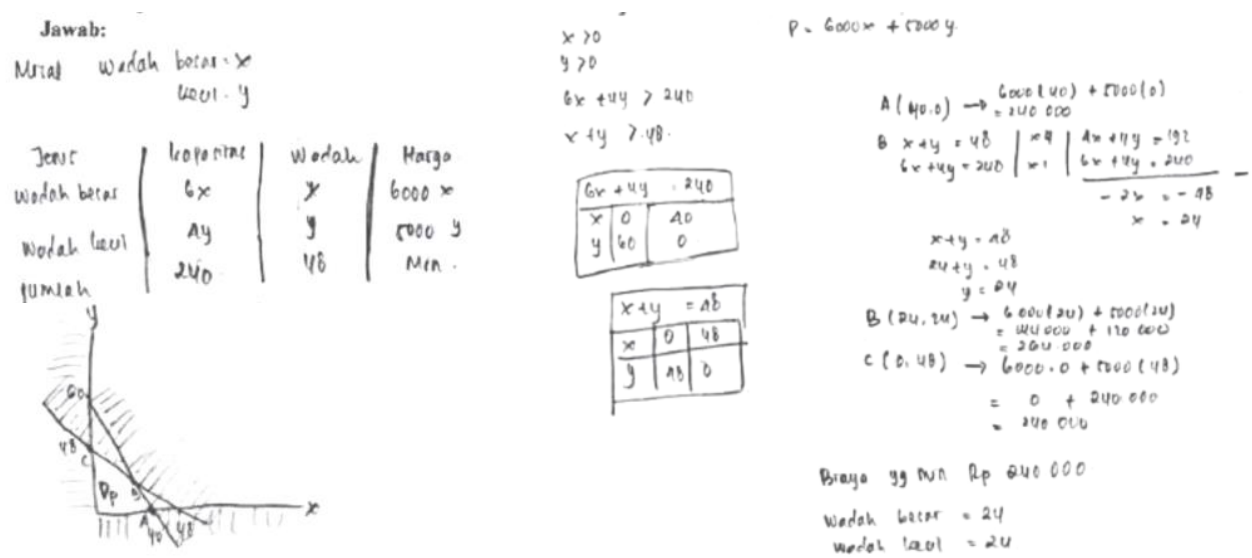

Fig 4. Example of students' answer on task 2

This student identified two problems, which were large and small containers and car capacity, while on the first question there are no car capacity problems. Therefore, this student has only one solution to the problem of renting large and small containers to carry 240 bottles of soy milk. They didn't understand that there are many solutions to solve this problem.

For task 3, many students are not able to work on the question because the complexity of the problem is harder than the other analytical problems. This is due to students' low ability to understand word problems. Many students are sluggish to comprehend word problems if the question is too long and complex.

Results for the synthetic stage can be seen in Table 3 below.

Table 3. For the synthetic stage, students achieved for each question

\begin{tabular}{lccc}
\hline & Generating & Planning & Producing \\
\hline \multirow{2}{*}{ Task 4 } & 0 & 0 & 0 \\
\cline { 2 - 4 } & $0 \%$ & $0 \%$ & $0 \%$ \\
\hline \multirow{2}{*}{ Task 5 } & 0 & 0 & 0 \\
\cline { 2 - 4 } & $0 \%$ & $0 \%$ & $0 \%$ \\
\hline
\end{tabular}

For solution planning problems, and error finding problem with an explanation of the error reason, most of the students only achieved the generating stage. It's means that the synthetics thinking ability of students were very low so they can't solve the solution planning problems, and error finding problem with an explanation of the error reason.

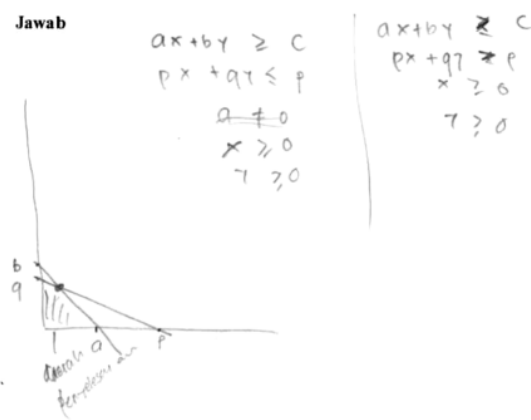

Another students' answer
Soal tidat memiliki penyelesaian.

Note: this problem didn't have a solution

Fig 5. Example of a students' answer on task 4 
The student determined the common form of probabilities of the linear inequalities system, then tried to portray this on a Cartesian coordinate system. This student was confused, portraying a linear inequalities system on a Cartesian coordinate system. In addition to that, there was another student who claimed that this problem has no solution. This student is unable to comprehend the question and does not describe a linear inequality system that has three probabilities, which have one solution, many infinite solutions, or no solutions. This is determined from the relationship between the coefficient and constant on the existing linear inequality system.
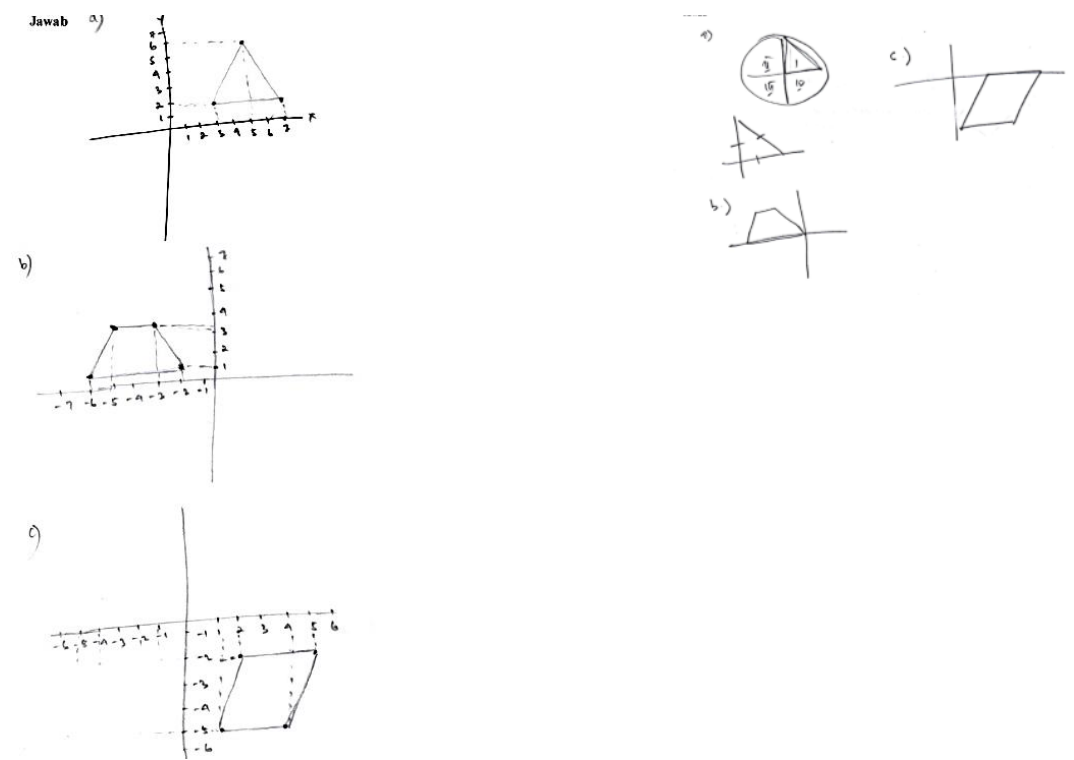

Fig 6. Example of two students' answers for task 5

Based on the two students' answers above, it is shown that they are not able to determine a linear inequality system that has the solution part of a model. The students are only able to determine the quadrant in its Cartesian coordinate and determine the form of a model and its coordinate. Most of the students solve the problem by determining the model first but not determining its linear inequality system.

According to the statistics for the synthetic result, it is found that the synthetic thinking skill level of all the students is at a low level. Therefore, the analytical and synthetic thinking skill levels of students in the 2018 class of the Mathematics Education Program of UKSW on linear program material is considered low level.

The analytical and synthetic thinking skill levels of students in the 2018 class of the Mathematics Education Program of UKSW are categorized as low. It is stated that analytical and synthetic thinking skills in the low categories have some characteristics as follows:

a. Distinguishing components in the problem situation

b. Distinguishing the processes

c. Finding dependencies between the components

d. Expressing some values through others

e. Identifying common and distinctive features in the objects and relationships between them

f. Finding similarities between the objects

g. Forming connections 
h. Demonstrating the understanding of the problem

i. Demonstrating the understanding of the sequence of actions to solve the problem

j. Generating an idea of the expected outcome of the problem solution

k. Planning activities to solve the problem

1. Adducing arguments that confirm availability of errors

m. Presenting facts explaining the reasons of the errors

Things that cause low analytical and synthesis thinking skills of students are as follows:

a. During high school, students are not getting used to facing High Order Thinking Skills (HOTS) questions and complex questions, especially analytical and synthetic questions.

b. Students are not getting used to facing synthetic problems resulting in low synthetic thinking skill levels, and therefore they only reach the generating stage.

c. In solving analytical problems, students will achieve all analytical stages if the questions given are simple, while for complex questions, students only reach the differentiating stage. This means students only comprehend the questions given and identify the information in the questions given.

d. Teachers admit that they do not teach students to the synthetic stage by considering students' abilities. This is supported by interview results of some mathematics teachers in Salatiga where they do not teach their students to the synthetic stage because they consider that there is too much material and that the inability of their students to understand make it impossible to teach to the synthetic/create stage.

e. Teacher has not taught and trained students with HOTS learning. Teacher can use learning problem solving and open-ended questions to develop analytical and synthetics thinking.

\section{Conclusion}

According to this research, it shows that the level of analytical and synthetic thinking skills of students in the 2018 class of the Mathematics Education Program of UKSW are relatively low. Also, based on the result of teaching materials analysis and interviews with the teachers, we conclude that improvement efforts are needed to develop students' analytical and synthesis thinking skills through the learning process.

\section{References}

[1] Moore, B., \& Stanly, T. 2010. Critical thinking and formative assessments. Larchmount, New York: Eye on Education, Inc

[2] Anderson L, Krathwohl D. 2001. A Taxonomy for Learning, Teaching, and Assessing: A Revision of Blooms Taxonomy of Educational Objective. Addison Wesley Longman, Inc

[3] Tanujaya B. 2016. Development of an instrument to measure higher order thinking skills in senior high school mathematics instruction. Journal of Education and Practice 7(21):144148

[4] Stenberg R, Kaufman J, Grigorenko E. 2011. Applied Intelligence. Pustaka Pelajar, Yogyakarta

[5] Bezunova T, Richter T, Sugrobova N, Chugainova L, Shestakova L. 2017. Types of working in forming analytic and synthetic activity skills in teaching the algebra course. Eurasia Journal of Mathematics, Sciences, and Technology Education 13(11):72577267

[6] Koldunova. 2015. The Model of Development of Analytic-Synthetic Component of Thinking of Future Teachers of Informatics When Teaching The Theory of Algorithms. Bulletin of Tomsk State Pedagogical University 
[7] Inam A. 2016. Logical thinking analysis through the euclidean geometry. Global Journal of Pure and Applied Mathematics 12(1):10691075

[8] Aksu G, Koruklu N. 2015. Determination the effects of vocational high school students logical and critical thinking skills on mathematics success. Eurasian Journal of Educational Research 15(59):8187, DOI https://doi.org/10.14689/ejer.2015.59.11

[9] Levin, I., \& Lieberman, E. 1998. Developing Analytical and Synthetic Thinking in Technology

Education, 1-5.

[10] Pardjono, Wardaya. 2009. Peningkatan Kemampuan Analisis, Sintesis, dan Evaluasi Melalui Pembelajaran Problem Solving, vol 3. Universitas Negeri Yogyakarta

[11] Yuniarti Y, Kusumah Y, Suryadi D, Kartasasmita B. 2017. The effectiveness of open-ended problems based analytic-synthetic learning on the mathematical creative thinking ability of pre-service elementary school teachers. International Electronic Journal of Mathematics Education. 12(3):655666

[12] Pallascio R, Allaire R, Mongeau P, Pallascio R, Allaire R, Mongeau P. 1993. The Development of Spatial Competencies through Alternating Analytic and Synthetic Activities mm 13(3):815

[13] Zachariades T, Christou C, Pitta-Pantazi D. 2013. Reflective, systemic and analytic thinking in real numbers. In: Educational Studies in Mathematics, vol 82, p 522, DOI https://doi.org/10.1007/s10649012-9413-y

[14] Stanton M, Welsh R. 2012. Systemic thinking in couple and family psychology research and practice. Couple and Family Psychology: Research and Practice 1(1):1430, DOI https://doi.org/10.1037/a0027461

[15] Ackoff R. 2004. Transforming the systems movement. Philidelphia, PA, URL http://www.acasa.upenn.edu/RLAConfPaper.pdf.

[16] Atwater J, Pittman P. 2006. Facilitating systemic thinking in business classes. Decision Sciences Journal of Innovative Education 4(2):273292, DOI https://doi.org/10.1111/j.1540-4609.2006.00117.x

[17] Rude, H., Gorman, \& Roxanne. 1999. Systemic Thinking to Support Dine Education. In Proceedings of the American Council on Rural Special Education (pp. 1-18).

[18] Tuan, N. T., \& Shaw, C. 2016. Consideration of Ethics in Systemic Thinking. Systemic Practice and Action Research, 29(1), 51-60. https://doi.org/10.1007/s11213-015-9352-5

[19] Amer A. 2005. Analytical Thinking. Pathways to Higher Education Project. Center for Advancement of Postgraduate Studies and Research in Engineering Sciences, Faculty of EngineeringCairo University

[20] Bartlett G. 2001. Systemic thinking: a simple thinking for gaining system (situation-wide) focus. The International Conference on Thinking Breakthroughs 2001 Prodsol International

[21] Montaku, S., Kaittikomol, P., \& Tiranathanakul, P. 2012. The Model of Analytical Thinking Skills Training Process. Research Journal of Applied Sciences.

[22] Passig D. 2003. A taxonomy of future higher thinking skills 